\title{
Biophilic Playgrounds as Playscapes in Child-Nature Interaction
}

\author{
Canan Cengiz \\ Bartin University, Faculty of Engineering, Architecture and Design, \\ Department of Landscape Architecture, Bartin, Turkey \\ E-mail: canancengiz@bartin.edu.tr \\ Aybuke Ozge Boz (Corresponding author) \\ Bartin University, Faculty of Engineering, Architecture and Design, \\ Department of Landscape Architecture, Bartin, Turkey \\ E-mail: aboz@bartin.edu.tr
}

\begin{abstract}
Playscapes encompass various physical activity opportunities with multiple environments such as forest areas and natural areas where seasonal changes can be observed. In this context, they provide playgrounds which contribute to the development psychology of children while strengthening the interaction between children and nature. Children have an innate biological tendency known as biophilia related with connecting to the natural world. Children experience nature not as a background for natural events but as a stimulant and component of their activities. Biophilic playgrounds provide significant spatial opportunities for children to be in direct contact with nature and to experience the natural environment in rural and urban areas. Biophilic playgrounds can be designed as natural environments where children are encouraged to play or as spaces that include topography, plants, trees, sand, logs, stone, water, wind, fire and other natural elements. Natural elements and materials provide open ended play opportunities that support creative discoveries. Nature with a high level of complexity and diversity reveals the potential of children to create longer and more complex plays. In the present study, biophilic playgrounds as playscapes with significant roles in child-nature interaction have been taken into consideration and the child-education-learning-nature relationship has been emphasized within the scope of biophilia. In this scope, the Singapore Nature Playgarden at Hortpark Example was examined in the study. In conclusion, the importance of biophilic playgrounds have been put forth in the study for providing ecological functions and habitats as well as for creating consciousness in children for developing empathy, discovering nature and protecting nature.
\end{abstract}

Keywords: Playscapes, Biophilic playgrounds, Child-Nature interaction, Children's nature experience

DOI: $10.7176 / J S T R / 5-12-23$

\section{Playscapes}

Playscape has been defined by Frost (1992) as a landscape that affords children the ability to play (Fjørtoft, 2004). The need for better play environments instead of fixed-equipment playgrounds has been emphasized by the term 'playscape' (Jansson, 2010).

Activities related with the planning and management of playscapes lead to diversity in landscape elements, affordances for play as well as challenges and safety; accessibility; and wear resistance. Vegetation and topography within the context of diversity in landscape elements may be considered as quality dimensions for natural playscapes. These playscapes make up the grounds for the training of motor fitness in children. The motor fitness of children improved by way of all-round playing and exploring in the natural playscape. This was an indication of the impacts of natural playscapes on the motor skills of children (Fjørtoft and Sageie, 2000).

Refraining from typical playground equipment, playscapes provide children with various types of physical landscapes for exploration along with stacked local rocks for climbing and crawling. Loose part settings including dirt, sand, and pebble as well as fallen logs comprise a variety of spaces inside the playscape (Gemmel, 2015). In this context, the Marge and Charles Schott Nature Playscape located at the state of Ohio in America has been set forth as an example (Figure 1, Figure 2). 


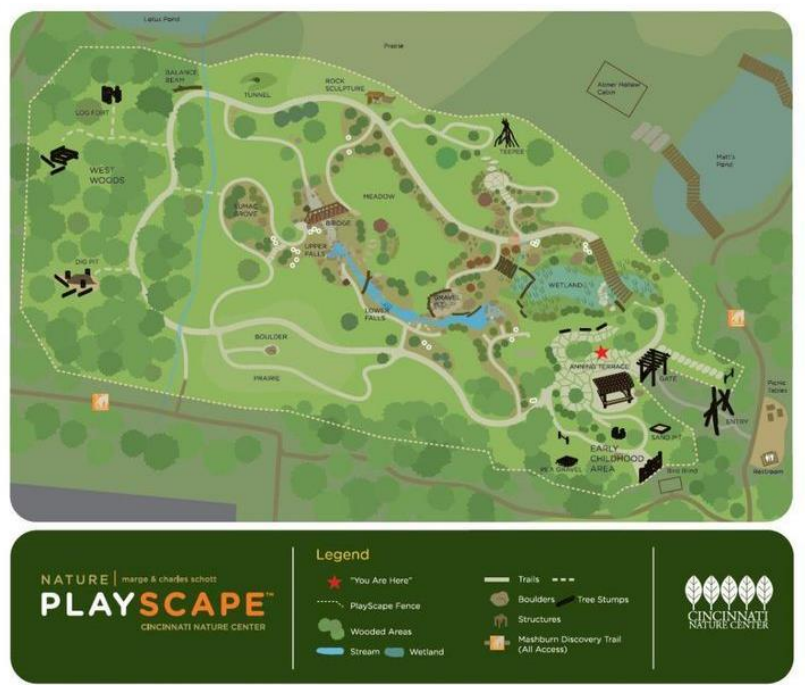

Figure 1. Marge and Charles Schott Nature Playscape (URL-1)

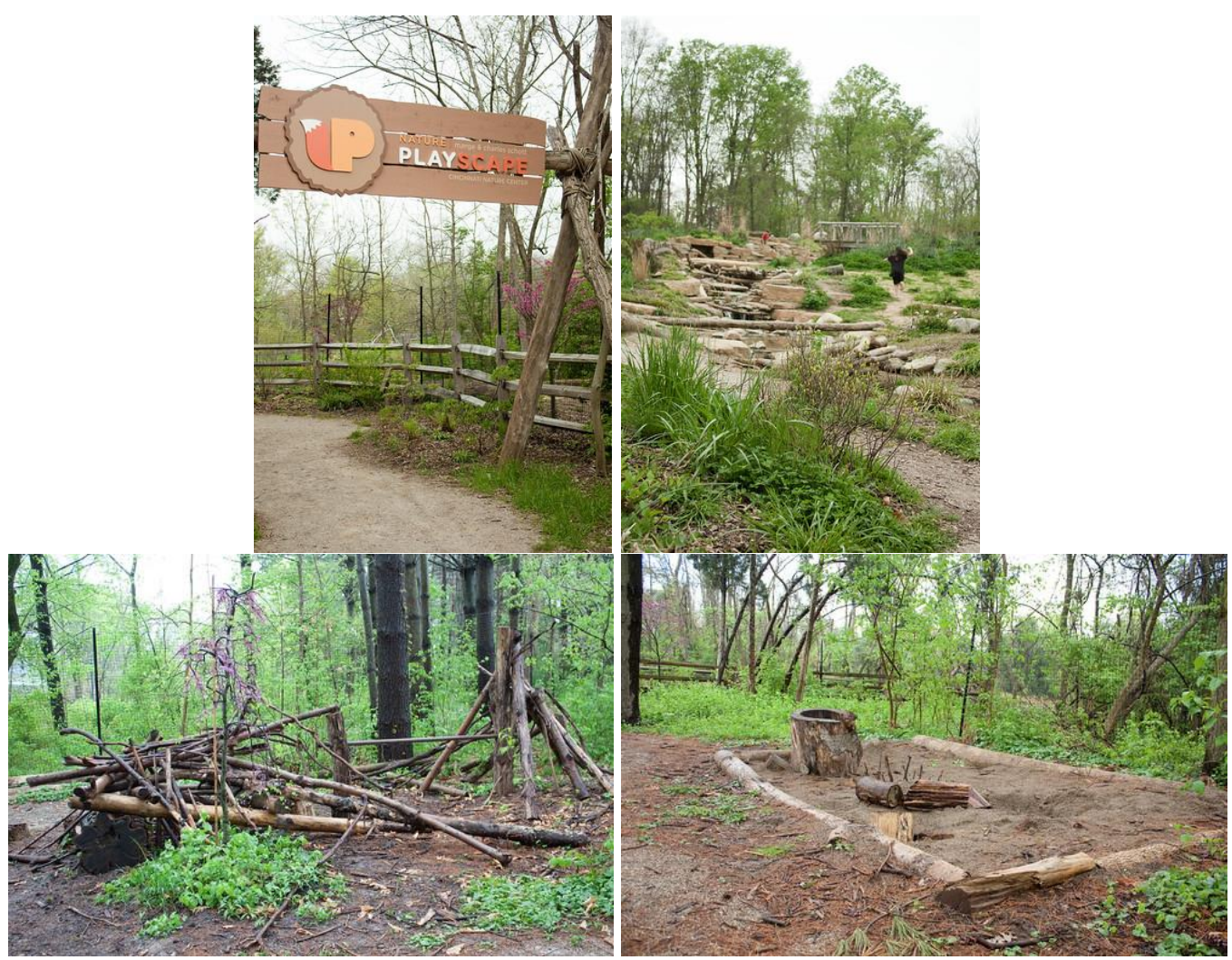

Figure 2. Images from the Marge and Charles Schott Nature Playscape (URL-2)

The experiences of children in natural environments are central to their personal development. Moore and Wong (1997) report that children are familiar to natural attractions such as small animals, water, sand, earth, trees, and plants (Ismail et al., 2015). According to Free Play Network (2008); playgrounds may both be indoors and outdoors but children mostly prefer outdoor playgrounds. Play spaces are also valuable for parents and caregivers of small children (Ismail et al., 2015). The Forestry Commission (2009) provided the following definition for natural playscapes: "a term used to describe the creation of simple play opportunities in the natural environment". They are referred to as nature parks, ecological parks or play parks in urban settings. The same design philosophies are utilized for these parks in order to accommodate in high use areas (Ismail et al., 2015). 


\section{Children's Experience with The Natural World}

According to Prescott (1987); outdoor play time differs significantly from time spent indoors with regard to sensory experiences and standards of play. Activities that are not suited for closed environments may be perfectly fine for outdoors. Children are able to run and shout more freely in addition to interacting with and manipulating the environment. They can do 'messy' activities with no worries outdoors which will not be tolerated indoors. The unending diversity of natural outdoor environments; the fact that they are not created by adults; and their feeling of timelessness - the landscapes, trees, rivers described in fairy tales and myths still exist today - are among the most important qualities that are tempting and exciting for children (White and Stoecklin, 1998).

According to Sebba (1991); the natural world is not a scene or even just a landscape. Nature is nothing short of sheer sensory experience for children (White and Stoecklin, 1998). According to Moore (1993); children judge the natural setting not by its aesthetics, but rather by how they can interact with the environment. Plants, together with soil, sand, and water, provide settings that can be manipulated. One can build a trench in the sand and dirt or a rock dam over a stream, but there's not much you can do with a jungle gym except to climb it, hang down from it, or fall off it (White and Stoecklin, 1998).

The following can be listed as factors which influence experiences with nature in natural playgrounds: useful nature, challenging nature, active nature, intriguing nature, fear and aversion to nature, fantasy in nature, aesthetic nature, non-natural experiences (Postma, 2016).

Activities below can be listed among those that children prefer in outdoor environments (White and Stoecklin, 1998):

- water

- vegetation, including trees, bushes, flowers and long grasses,

- animals, creatures in ponds, and other living things

- $\quad$ sand, best if it can be mixed with water

- natural color, diversity and change

- places and features to sit in, on, under, lean against, and provide shelter and shade

- different levels and nooks and crannies, places that offer privacy and views

- structures, equipment and materials that can be changed, actually or in their imaginations, including plentiful loose parts.

Titman (1994) put forth the preferences of children for outdoor play environments in a very clear manner. Colors in nature, trees, woodlands, shifting topography, shaded areas, meadows, places for climbing and construction, and challenging places for exploring and experience are among the environmental qualities that are preferred the most by children. This is an indication that children have a desire for more complex, challenging and exciting play environments rather than the traditional playgrounds usually offered (Fjørtoft, 2004).

\section{- Childhood Periods}

There are three fundamental stages related with the development of environmental values in children and their environmental education (URL-3).

- Early childhood (between $3 / 4$ to 7 years of age)

The primary objective of environmental education in early childhood should be to develop empathy between the child and the natural world. One of the best methods of developing empathy in small children is to develop their relationships with animals in addition to opportunities for discoveries and plays in nature (URL-3).

Gross and fine motor skills are developed during early childhood by way of activities such as climbing, swinging and balancing. Imaginative play can take place anywhere as far as we allow it. Play with loose parts provide opportunities for children to take something and re-purpose it. A recycling bin is transformed into a den, a snail's house, a seat, a climbing platform, a stepping stone or a sledge subject to the imagination of the child (URL-4).

- Early / secondary school (7-11 years of age)

The primary objective for this 'bonding with the earth' stage of environmental education is ensuring the exploration of the nearby world and learning your place inside it (URL-3).

- Adolescent period (12 to 17 years of age)

Social action begins properly at around the age of 12 moving onto the ages of 17 and above. Children tend to be inclined toward desires to save the world, assuming of course that they have the opportunities in their earlier years to develop empathy for and to explore the natural world as they start to discover the 'self' of adolescence and feel their connectedness to society (URL-3). 


\section{Biophilia-Child-Play Relationship}

Children have an innate biological tendency known as biophilia for connecting to the natural world. Proper developmental opportunities should be provided to the children in order to ensure that they acquire information based on the sound principles of child development and learning and to improve their natural biophilia tendencies. Children experience the natural environment different than the adults. Adults generally see nature as a background for the work they do or as an aesthetic experience. Children see nature not as a background for events and they experience it as a stimulant and experiential component of their activities (URL-3).

Biophilic design establishes the connection between sensory gardens, dementia gardens and natural playgrounds. Nature is designed back in to the cities, workplaces, homes, schools and hospitals. Nature, health and well-being are bound together with an ever growing pool of evidence (URL-4).

Aversion to nature known as biophobia may develop when the natural attraction of children cannot flourish during their growth period. The impacts of biophobia vary from discomfort in natural places to contempt for all that is not man-made, managed or air-conditioned. Biophobia also manifests itself as opinions that regard nature as nothing more than a disposable resource (URL-3).

Natural playgrounds are sustainable playgrounds. Sustainable communities are promoted by way of sustainable playground design. Healthy eating at home shall be supplemented by way of picnic areas with edible, playable planting encouraging families to amble and enjoy a wide range of outdoor play opportunities (URL-4).

There are two reasons why the dwindling connection of children with nature and the suppression of the expression of biophilia are alarming. First is the fact thaton the health and well-being of children are affected adversely from lack of access to greenspace and time spent outdoors which is related with increasing obesity and a rather reduced ability for problem-solving and evaluating risks, which in turn have negative impacts on mental well-being. Second, a loss of motivation to protect nature may develop as a result of inadequacies related with early connection to nature. A lifelong connection to nature is possible only by way of early childhood experiences. The ever-increasing divide is put forth dramatically by reports of children with fear of nature or inability to name common wildlife species. Children with the least exposure to nature display this detachment strongly. The use of different urban habitats by children and their selection of habitats based on relative use and availability did not conform to the biophilia hypothesis (Hand et al., 2016).

\section{Child-Education-Learning-Nature Relationship within the scope of Biophilia}

The learning types of children are completely different from those of adults. The environmental education of children should be designed to meet the developmental needs of children, their interests, abilities and learning styles in order to be effective. Small children are active learners. They can learn best by way of applied, interactive plays and discoveries instead of trying to provide knowledge. Small children have an innate curiosity that required direct sensory experience rather than conceptual generalizations. The emotional bonds of children with nature develop earlier than their abstract, logical and rational viewpoints. We should enable children to develop and nurture their biophilia, their love for the Earth before asking them to learn academic knowledge or demanding them to be protective (URL-3).

According to Wilson (1997); children have a unique, direct and experiential way of knowing the natural world as a place of beauty, mystery and wonder. The unique affinity of children for the natural environment is strongly bound to their development and way of knowing (White and Stoecklin, 1998).

Empathy and love for nature together with their positive environmental behaviors and attitudes result from the fact that children are in regular contact with the natural world as well as the fact that they play games (URL-3).

According to Moore (1996); there are no man-made equipment or indoor instructional materials produced by the best educators in the world which can take the place of essential hands-on experience in nature. It is by no means possible to capture the attention of the child as when natural phenomena sparks an interest in them such as the dappled sparkle of sunlight through leaves, the sound and motion of plants in the wind, the sight of butterflies or a colony of ants, the imaginative worlds of a square yard of dirt or sand, the endless sensory experience of water, the infinite space in an iris flower (White and Stoecklin,1998).

\subsection{Plants}

Plants are vital. Indeed, ecological theming with vegetation may be the solution for creating identities for many of the playgrounds. For instance, a bog or stream habitat may be used for setting up an interactive water play. It is also crucial that ecological areas utilizing indigenous vegetation and settings are integrated in order to ensure that children are able to experience, learn about and develop an appreciation of their local environment (White and Stoecklin,1998). 
The importance of shading trees in natural playgrounds increase with the changing climate. Edible fruit trees around playgrounds provide shade, scented blossom, add bio diversity and most importantly add to locally produced food stocks, thereby promoting healthy living and eating (URL-4).

Children are left on their own devices in natural playgrounds to come up with unique ideas for plays and use their imaginations rather than having specific activities (Fjørtoft, 2004).

Trees and other plants grow and change with the seasons in natural playgrounds. Different colors are provided throughout the year by flowers and fruits. Playground with young trees change drastically over a period of 5-10 years as trees grow taller, and in case they are deciduous, the trees will shed and replace their leaves every year. Children are presented with a wide range of materials to play with, collect, and build with such as leaves, pine cones, seed pods, branches and thatch material (Fjørtoft and Sageie 2000). According to Moore (1993); plants appeal to all our senses and thusit is in no way surprising that children are closely attuned to environments with vegetation. Plants, in a pleasant environment with a mix of sun, shade, color, texture, fragrance, and softness of enclosure also encourage a sense of peacefulness (White and Stoecklin, 1998). Biophilic playgrounds are sustainable when plants are used that are suited to the microclimate with less fertilizer and water input.

\subsection{Animals}

Biophilic playgrounds also act as "discovery play gardens". Children find the chance to manipulate the environment and explore, to wonder and experiment, to pretend, to understand themselves, and to interact with nature, animals and interesting insects in discovery play gardens (White and Stoecklin,1998).

Children are able to establish direct contact with plants, animals, and water by way of wildlife habitats in addition to acquiring support with regard to teaching the connectivity of life and thus it is important to create, maintain and restore wildlife habitats (Derr and Lance, 2012).

In this scope, biophilic playgrounds provide opportunities to observe, examine and recognize animals and insects. Bug houses, butterfly gardens, bird hosting trees and shrubs along with rain gardens established to enable the children to observe mosquitoes and all other living things in the swamp ecosystem are important for nature-child interaction.

\subsection{Materials Specification-Surfacing}

According to Moore (1993); unstructured creative exploration with diverse materials is accentuated by way of open ended play provided by natural elements. Longer and more complex play times are thus experienced resulting from the high levels of complexity and variety that nature offers. Plants trigger discovery, dramatic pretend play, and imagination thanks to their interactive characteristics (White and Stoecklin, 1998).

Children may learn about and develop stewardship and connection to the environment when they are exposed to natural materials and processes (White and Stoecklin, 1998). The time spent by children in environments that resemble nature may be increased by integrating playscapes into school playgrounds and public parks (Shackell et al., 2008).

According to Wilson (1997); openness, diversity, manipulation, exploration, anonymity and wildness are among the qualities offered by natural settings and materials (White and Stoecklin, 1998).

\section{Biophilic Design Application on Playgrounds}

Design principles related with playgrounds arranged in accordance with biophilic design principles are presented in Table 1 along with spatial and design considerations. 
Table 1. Biophilic design guidelines for playgrounds (Nogueira, 2017)

\begin{tabular}{|c|c|c|}
\hline \multicolumn{3}{|c|}{ Biophilic Design Principles Applied to Playgrounds } \\
\hline $\begin{array}{l}\text { Biophilic Design } \\
\text { Principles }\end{array}$ & Spatial Configuration & Design Consideration \\
\hline $\begin{array}{l}\text { 1. Visual Connection } \\
\text { with Nature }\end{array}$ & $\begin{array}{l}\text { Spaces and play elements } \\
\text { integrated with nature }\end{array}$ & Nature as part of a play elements \\
\hline $\begin{array}{l}\text { 2. Non-Visual } \\
\text { Connection with } \\
\text { Nature }\end{array}$ & $\begin{array}{l}\text { Spaces with a positive sensorial } \\
\text { stimulus that resemble nature }\end{array}$ & $\begin{array}{l}\text { Features that promote sounds of water } \\
\text { and a garden with edible plants }\end{array}$ \\
\hline 3.Presence of Water & $\begin{array}{l}\text { Spaces and play elements with } \\
\text { water }\end{array}$ & $\begin{array}{l}\text { Fountain, rain garden, water channel, } \\
\text { etc. integrated with play elements and } \\
\text { overall site design }\end{array}$ \\
\hline $\begin{array}{l}\text { 4. Dynamic and } \\
\text { Diffuse Light }\end{array}$ & $\begin{array}{l}\text { Play elements or spaces that } \\
\text { allows dramatic light and shade }\end{array}$ & $\begin{array}{l}\text { Diversified openings for varied } \\
\text { sunlight incidences }\end{array}$ \\
\hline $\begin{array}{l}\text { 5. Connection with } \\
\text { Natural Systems }\end{array}$ & Integration with natural systems & $\begin{array}{l}\text { Rain garden and deciduous trees as part } \\
\text { of site design and overall landscape }\end{array}$ \\
\hline $\begin{array}{l}\text { 6. Biomorphic Forms } \\
\text { and Patterns }\end{array}$ & $\begin{array}{l}\text { Spaces with organic shapes and } \\
\text { patterns and avoidance of right } \\
\text { angles }\end{array}$ & $\begin{array}{l}\text { Utilization of curves and organic } \\
\text { shapes to design play elements and } \\
\text { overall site design }\end{array}$ \\
\hline $\begin{array}{l}\text { 7. Material } \\
\text { Connection with } \\
\text { Nature }\end{array}$ & $\begin{array}{l}\text { Spaces designed with natural } \\
\text { materials }\end{array}$ & $\begin{array}{l}\text { Wood, stone and sand integrated with } \\
\text { play elements and overall site design }\end{array}$ \\
\hline 8. Prospect & $\begin{array}{l}\text { Spaces that allows open views } \\
\text { beyond the immediate } \\
\text { surroundings }\end{array}$ & $\begin{array}{l}\text { Elevated spaces that allow for } \\
\text { unobstructed views and play elements } \\
\text { that can be climbed }\end{array}$ \\
\hline 9. Refuge & $\begin{array}{l}\text { Spaces that promote protection } \\
\text { from behind and overhead }\end{array}$ & $\begin{array}{l}\text { Enclosure type of play element and } \\
\text { spaces that promote a sense of } \\
\text { protection and rest }\end{array}$ \\
\hline 10. Mystery & $\begin{array}{l}\text { Spaces that encourage one to } \\
\text { further investigate and that } \\
\text { promote a sense of reward at the } \\
\text { end }\end{array}$ & $\begin{array}{l}\text { Curved edges with the use of dramatic } \\
\text { light and shade within play elements } \\
\text { and spaces and with obstructed or } \\
\text { unreachable view }\end{array}$ \\
\hline 11. Risk/Peril & $\begin{array}{l}\text { Spaces that permitting the } \\
\text { experience of risk without } \\
\text { plants }\end{array}$ & $\begin{array}{l}\text { Play elements or spaces that allow for } \\
\text { experiment with height, gravity, speed } \\
\text { and water (e.g. perception of falling or } \\
\text { getting wet). }\end{array}$ \\
\hline 12. Plants & Spaces integrated with plants & Gardens with trees and other plants. \\
\hline 13. Images of Nature & $\mathrm{N} / \mathrm{A}$ & $\begin{array}{l}\text { Sculptures of animals or plants and } \\
\text { play elements with shapes of nature } \\
\text { (e.g. animals and plants) }\end{array}$ \\
\hline 14. Natural Colors & $\begin{array}{l}\text { Colors applied to play elements } \\
\text { and site design }\end{array}$ & $\begin{array}{l}\text { Pastel and earth tones with the } \\
\text { avoidance of bright colors }\end{array}$ \\
\hline $\begin{array}{l}\text { 15. Transitional } \\
\text { Spaces }\end{array}$ & $\begin{array}{l}\text { Clear and visible transitions } \\
\text { with connections between } \\
\text { spaces }\end{array}$ & $\begin{array}{l}\text { Threshold, portal or areas that link the } \\
\text { indoors with the outdoors }\end{array}$ \\
\hline $\begin{array}{l}\text { 16.Cultural and } \\
\text { Ecological } \\
\text { Attachment to Places }\end{array}$ & $\begin{array}{l}\text { Spaces that promote an } \\
\text { ecological connection to a place }\end{array}$ & $\begin{array}{l}\text { Use of indigenous flora and locally } \\
\text { available material }\end{array}$ \\
\hline
\end{tabular}




\section{Singapore Nature Playgarden at Hortpark Example}

It has been put forth as a result of studies carried out that interacting with the outdoors helps children develop creativity based on the concept of "biophilia", the innate emotional connection that humans have with nature. A new biophilic playground at HortPark has been specially designed to allow children to play freely in nature (URL-5).

The Nature Playgarden at HortPark has been designed with greenery and natural sounds for preschoolers to encourage children to spend more time outdoors and reconnect with nature. The imaginations of children may flow freely as they explore the nine different play features (Figure 3) (URL-6).

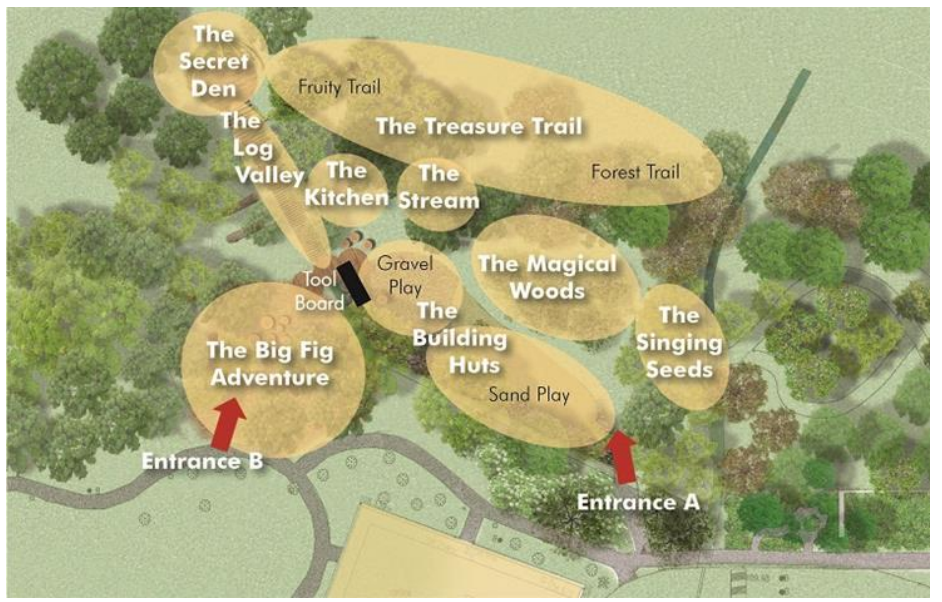

Figure 3. Nine different play features of the HortPark Nature Playground

\subsection{The Building Huts}

These two zones feature three teepees where the ground is filled with sand and gravel respectively. The use of sand and gravel enables the children to create structures, modify the landscape, or interact with the medium. All teepees have open sides thereby allowing the children to build using twigs, branches, or large dried fronds they can find in the play areas. This triggers creativity further alleviating the development of their motor skills while also enabling them to develop their communication and social skills through and through teamwork and playing together. Children cooperate to build houses and castles using natural materials such as timber cookies, wooden poles and tools provided at the Tool Board next to The Building Huts. This in turn inspires the children employ their imagination (URL-6) (Figure 4).

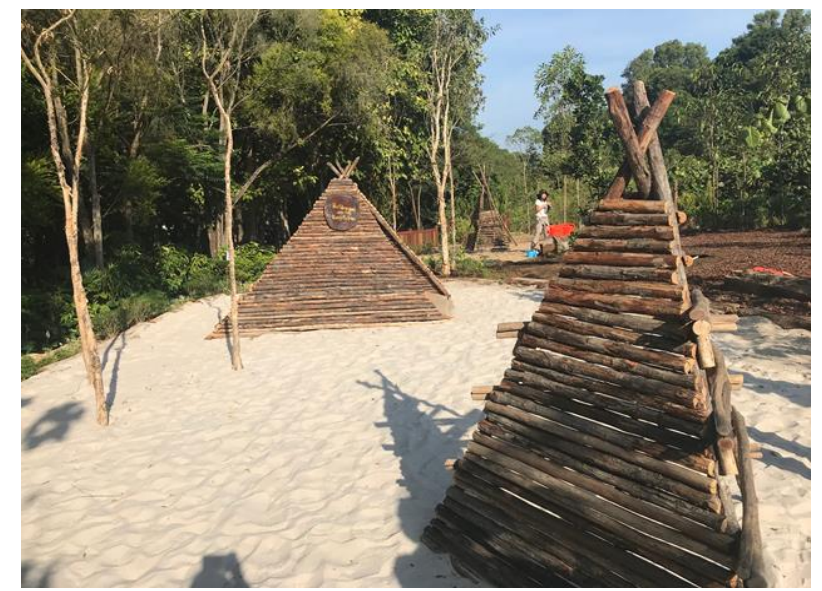

Figure 4. The buildings huts at HortPark Nature Playground (URL-7)

\subsection{The Singing Seeds}

Hanging bamboo poles of different sizes have been used in this area allocated for musical play where different pitched chimes are heard as children move the poles, or when the wind blows. Hollow musical seesaws and wheels filled with seeds from the Saga Tree (Adenanthera pavonina), Rubber Tree (Hevea brasiliensis) and seed pods of the Rattleweed (Crotolaria retusa) are also available where children can rock and spin to listen to the percussion of the rolling seeds. This enables them to establish a sensory connection with nature by way of sounds and different materials of the equipment (URL-6) (Figure 5). 


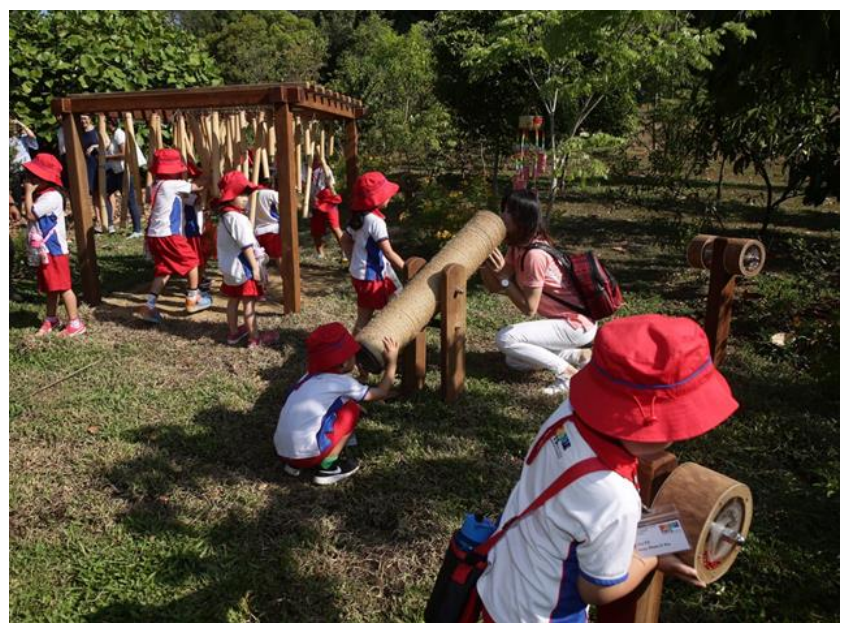

Figure 5. The Singing Seeds at the HortPark Nature Playground (URL-8)

\subsection{The Magical Woods}

A series of tunnels and hideouts for children are created by way of clusters of Dillenia species including Dillenia excelsa, D. philippinensis and D. suffruticosa create which in turn enables the children to explore, or seek refuge from the main flow of activity. Children can also move closer to the plants and observe the birds and insects which pollinate the flowers and eat the fruits of the Dillenia species (URL$6)$.

\subsection{The Stream}

The children will come across water flowing through a series of channels carved from logs in this area. Their senses are stimulated by the sight and feel of water enabling them to explore materials which can float or sink, thus wielding the flow of water as they construct their own dams as part of an imaginative play (URL-6) (Figure 6).

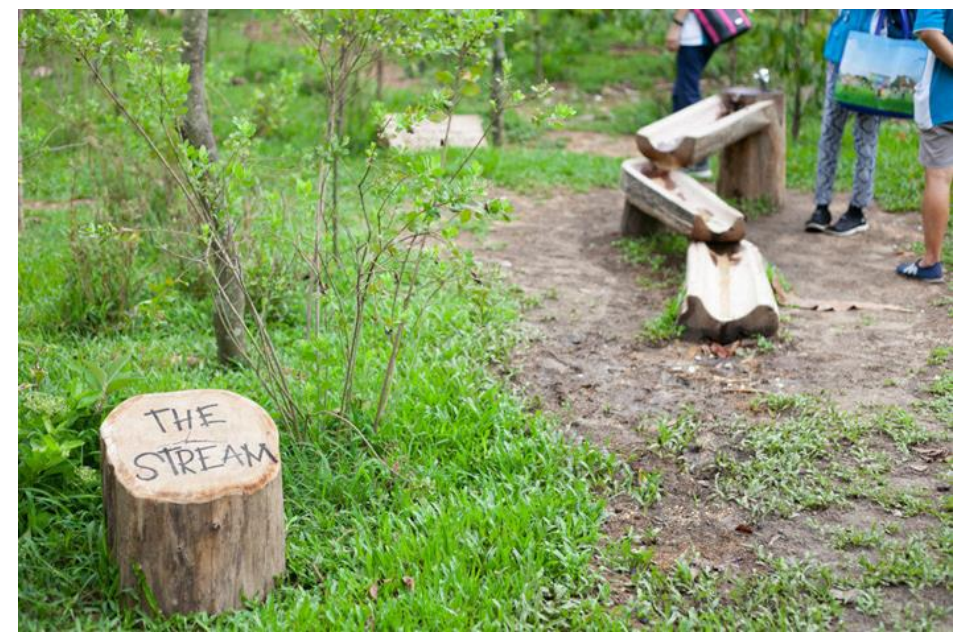

Figure 6. The stream area at the HortPark Nature Playground (URL-9).

\subsection{The Kitchen}

The kitchen area has a table surrounded by fruit trees in The Treasure Trail where children can pretend to cook with some cooking tools. Loose materials such as dried fruits and leaves are to be found here in boxes as "ingredients" which can be used by children in their imaginative plays (URL-6).

\subsection{The Big Fig Adventure}

This log play area within a grove of Fig Trees features a collection of logs that are made into steps, a table for gatherings, and a log hill. The stepping stones enable the children to challenge themselves as they climb, balance, or jump while also developing their motor skills and physical fitness in addition to establishing a material connection with nature (URL-6) (Figure 7). 


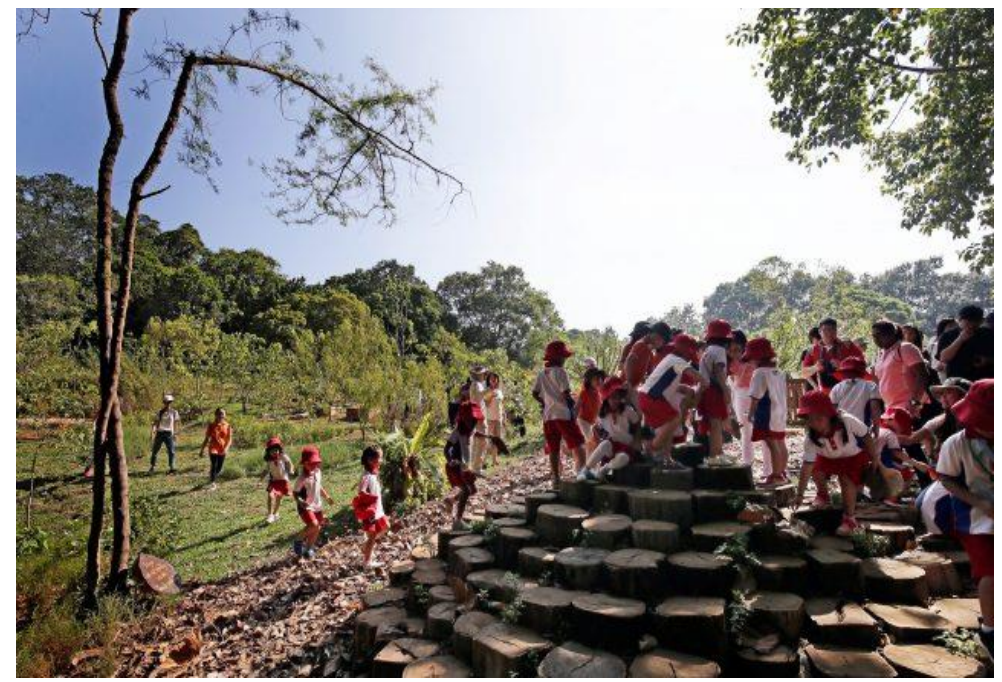

Figure 7. The Big Fig Adventure area at the HortPark Nature Playground (URL-10)

\subsection{The Log Valley}

Children can climb or balance as they explore the valley made of logs. The logs have been placed along the existing topography of the area. This enables the children to develop physical fitness, motor and social skills while promoting their levels of self-efficacy. The Kitchen is connected to The Big Fig Adventure by a series of crossing decks made of logs. The children can also observe the flow of water in the drain after the rain enhancing the experience of the place through seeing and hearing water alluding to the natural process of the water cycle (URL-6) (Figure 8).

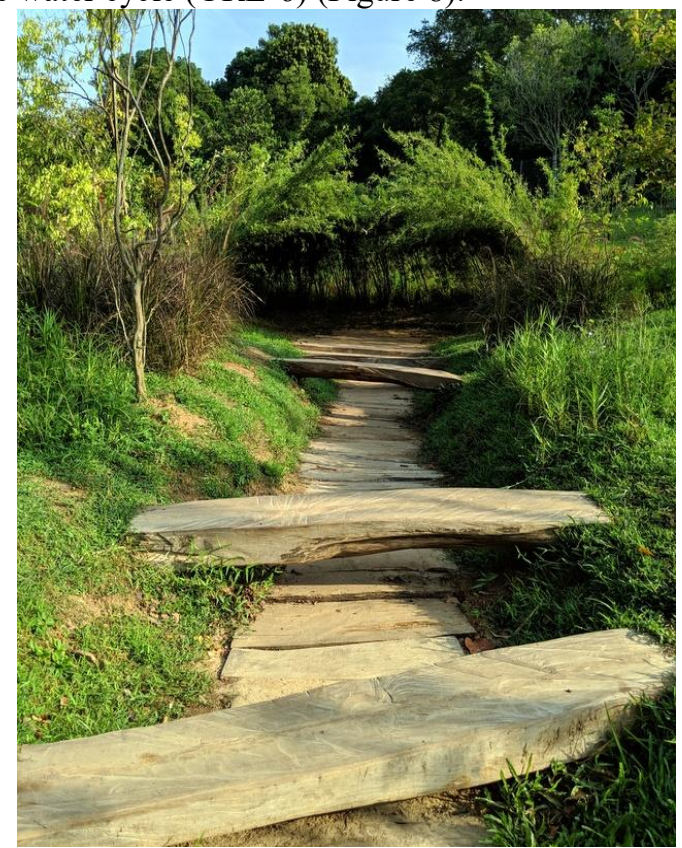

Figure 8. The Log Valley at the HortPark Nature Playground (URL-11).

\subsection{The Secret Den}

Children can take shelter from the elements, or spend some quiet time by themselves or bond in small groups under a grove of bamboo. An additional dimension is added to the environment as sunlight shines through the bamboo generating diffuse lighting with changes in light and shadow as time passes. Children can also peek out and overlook The Log Valley (Figure 9) (URL-6). 


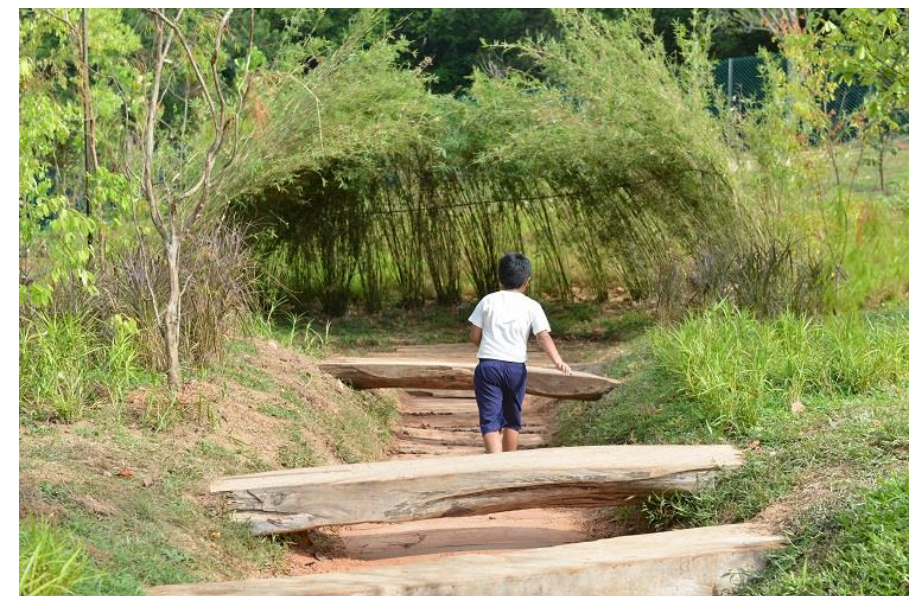

Figure 9. The Secret Den at the HortPark Nature Playground (URL-6).

\section{Conclusion and Evaluation}

Biophilic playgrounds can be built in natural environments such as forested areas where children are encouraged to play or they can be designed as spaces including elements of nature such as topography, plants, trees, sand, logs, stones, water, wind, fire and other natural elements. Schools also provide opportunities to the children to be a part of the process with regard to natural play opportunities and benefits. Biophilic playgrounds may provide ecological functions and habitats while also educating the children regarding the value of natural systems.

Fjørtoft and Segeie (2000) carried out a study in which it was emphasized that children playing in biophilic playgrounds have better motor skills, balance and coordination in comparison with children playing in traditional playgrounds.

Biophilic playgrounds are more encompassing with regard to designing different plays and displaying skills since they have different textures, materials and spatial characteristics when compared with typical playgrounds. They provide more attractive opportunities in comparison with the most modern or traditional playgrounds with regard to natural materials, workability and adaptability. The need for flexibility and adaptability are among the primary factors that should be taken into consideration when designing biophilic playgrounds as sustainable playgrounds.

In conclusion, less behavioral problems and injuries are observed in biophilic playgrounds since a greater number of children with different skills and ability levels can play a greater variety of plays at one time. Biophilic playgrounds provide opportunities to the children to develop empathy and discover nature thereby helping them to develop a tendency for acquiring a consciousness of protecting nature. They also have positive impacts on the obesity, mental and physical problems and evaluation skills of children.

\section{References}

Derr, V. and Lance, K. (2012). Biophilic Boulder: Children's Environments That Foster Connections to Nature. Children, Youth and Environments, 22(2), 112-143.

Fjørtoft, I. (2004). Landscape as Playscape: The Effects of Natural Environments on Children's Play and Motor Development. Children, Youth and Environments, 14 (2), 21-44.

Fjørtoft, I. and Sageie, J. (2000). The Natural Environment as a Playground for Children Landscape Description and Analyses of a Natural Playscape. Landscape and Urban Planning, 48, 83-97.

Gemmel, J. (2015). Rethinking Playgrounds: A Design Investigation of Playscape Theory. University of Maryland, Master Thesis, USA.

Hand, K. L., Freeman, C., Seddon P. J., Recio, M. R., Stein, A., Van Heezik Y. (2016). The Importance of Urban Gardens in Supporting Children's Biophilia. Proceedings of the National Academy of Sciences, 114(2), 1-6. DOI: 10.1073/pnas.1609588114, https://www.pnas.org/content/114/2/274. 
Ismail, N. A., Safiullah S. B., Yunos M. Y. M., Utaberta, N., Ismail, S. (2015). Identifying Natural Playscape Elements in a Neighbourhood Park: A case Study of Kuantan, Malaysia. Advances in Environmental Biology, 9 (5), 504-513.

Jansson, M. (2010). Attractive Playgrounds: Some Factors Affecting User Interest and Visiting Patterns. Landscape Research, 35 (1), 63-81.

Nogueira P. G. I. (2017). Biophilic Playspace Design: Bringing Together Children and Nature in Urban Honolulu. University of Hawai'i at Mānoa, PHD Thesis, USA.

Shackell, A., Butler, N., Doyle, Phil., Ball, D. (2008). Design for Play: Guide to Creating Successful Play Spaces. Edited by DCMS: Department of Children, Schools and Families Publications.

White, R. and Stoecklin, V. L. (1998). Creating Outdoor Play \& Learning Environments: Returning to Nature. Early Childhood News, March/April. Retrieved from: https://www.whitehutchinson.com/children/articles/outdoor.shtml

\section{Internet References}

URL-1 https://constantine.typepad.com/.a/6a0120a7fc3be9970b015393646f64970b-pi

(A.D. 20.11.2019)

URL-2https://www.theriskykids.com/2012/04/nature-playscape-at-the-cincinnati-nature-center/ (A.D. 20.11.2019)

URL-3http://www.communityplaythings.com/resources/articles/2008/nurturing-childrens-biophiliaenvironmental-education-for-young-children (A.D. 21.11.2019)

URL-4http://www.greenstonedesign.co.nz/natural-play.html (A.D. 21.11.2019)

URL-5https://www.todayonline.com/singapore/nparks-opens-nature-playground-hortpark-testbedfuture-biophilic-sites (A.D. 23.11.2019)

URL-6https://www.nparks.gov.sg/gardens-parks-and-nature/parks-and-naturereserves/hortpark/nature-playgarden (A.D. 23.11.2019)

URL-7https://mothership.sg/2019/03/playgarden-hort-park-children-nature/ (A.D. 23.11.2019)

URL-8https://www.straitstimes.com/singapore/planting-the-seeds-for-new-playground-design-athort-parks-new-nature-playgarden (A.D. 23.11.2019)

URL-9https://singaporemotherhood.com/articles/2019/09/hortpark-nature-playgarden-magicalgarden/ (A.D. 23.11.2019)

URL-10https://www.youngparents.com.sg/family/nature-playgarden-hortpark-free-outdoorplayground-preschooler/ (A.D. 23.11.2019)

URL-11 http://www.cheekiemonkie.net/2019/04/nature-playgarden-at-hortpark-kids-review.html (A.D. 23.11.2019) 